\title{
ANTIGÜEDAD, COSTUMBRE Y EXENCIONES FRENTE A INNOVACIÓN EN UNA INSTITUCIÓN MEDIEVAL: EL CONFLICTO ENTRE EL MAESTRESCUELA Y EL CABILDO DE LA CATEDRAL DE BURGOS (1456-1472)*
}

\author{
POR \\ Susana Guijarro GonZÁlez \\ Investigadora Ramón y Cajal \\ Departamento de Ciencias Históricas \\ Universidad de Cantabria
}

\begin{abstract}
RESUMEN
El artículo estudia las consecuencias que tuvo para el cabildo de la Catedral de Burgos la introducción de la dignidad de maestrescuela entre sus miembros a mediados del siglo XV. El prolongado conflicto que enfrenta al maestrescuela con el cabildo pone de manifiesto la extraordinaria habilidad desarrollada por la institución para eludir la justicia pontificia y episcopal. Su fuerza reside en la primacía de sus estatutos y costumbres históricas; y, sobre todo, en la dependencia directa de la sede burgalesa de la Corte pontificia. La lejanía de Roma permitía cierta libertad en la práctica. En el mismo contexto en que el Obispo Acuña trató de aplicar sus reformas, el maestrescuela se enfrentó al debate planteado por el cabildo burgalés entre tradición e innovación.
\end{abstract}

PALABRAS CLAVE: Cabildos catedralicios, Maestrescuela, Conflictividad eclesiástica, Burgos, Corona de Castilla, Siglo XV.

\section{ABSTRACT}

This article studies the consequences that the introduction of the «maestrescuela» (schoolmaster) rank had for the members of the Cathedral chapter of Bur-

\footnotetext{
* Este estudio se ha realizado en el marco del proyecto de investigación financiado por la Dirección General de Investigación del MEC, HUM2004-02313/HIST, titulado Saber y poder en la Castilla medieval (siglos XIV-XV): cultura y carreras profesionales entre el clero de las catedrales.
} 
gos in the middle of the fifteenth century. The long conflict, which set the schoolmaster against the Cathedral chapter, illustrates the extraordinary ability that had been developed by this institution to avoid Papal and Episcopal justice. The strength of this ability resided in the primacy of its historical statutes and customs. And, above all, on the direct dependence of the Burgos Episcopal See to the Papal Court. In practice, the remoteness of Rome allowed a certain degree of freedom. In the same context in which Bishop Acuña tried to carry out his reforms, the schoolmaster had to deal with the debate put forward by the Burgos Cathedral chapter between tradition and innovation.

KEY WORDS: Cathedral chapters, Schoolmaster, Ecclesiastical conflicts, Burgos, Castile kingdom, Fifteenth century.

Recibido/Received 12-04-2007

Aceptado/Accepted 19-06-2207

A diferencia del resto de los cabildos que se configuraron en las catedrales castellano-leonesas desde mediados del siglo XI, el de la Catedral de Burgos no contó con la figura del maestrescuela entre sus dignidades hasta el siglo XV1. La vida en común, que practicaron muchos de estos cabildos hasta el siglo XII, fue abandonada en el de Burgos a lo largo de la segunda mitad de dicha centuria ${ }^{2}$. A comienzos del siglo XIII, entre las dignidades del cabildo se encontraban el deán, el capiscol o cantor, el tesorero, seis arcedianos (Burgos, Lara, Treviño, Palenzuela, Valpuesta y Briviesca) y seis abades (Foncea, Castrojeriz, San Pedro de Cervatos, Salas de Bureba, San Millán de Lara y San Quirce). A ellos se sumaban por entonces treinta canónigos ${ }^{3}$. En 1396 el cabildo se componía ya de 15 dignidades, 50 canónigos, 16 porcionarios o racioneros y 18 medio racioneros ${ }^{4}$.

Hasta 1456 las fuentes documentales del cabildo no testimonian la presencia de la figura del maestrescuela entre sus dignidades. Las Actas Capitulares o Libros de Registros documentan una serie de episodios de enfrentamientos del maestrescuela con el cabildo y, en particular, con algunos de sus miembros, que

\footnotetext{
${ }^{1}$ En el Obispado de Coria la escolastría se instituyó en 1421 a instancias del Obispo Martín de Galos, $c f$. Vicente Beltrán de Heredia, Cartulario de la Universidad de Salamanca (1218-1600), vol. 1, Salamanca, 1970, p. 414.

${ }^{2}$ Sobre la vida en común del clero pueden verse los estudios publicados en La vita comune del clero nei secoli XI e XII en Atti della Settimana di Studio: Mendola, setiembre 1959, 2 vols., Milán, 1962. En concreto, para el clero catedralicio de los reinos hispanos véase Eduardo CARRERO SANTAMARÍA, «Ecce quam bonum et quam iocundum habitare frates in unum. Vidas reglar y secular en las catedrales hispanas llegado el siglo XII», en Anuario de Estudios Medievales, 30/2 (2000), pp. 757-805.

${ }^{3}$ Gonzalo MARTínez DíEz, «La Iglesia de Burgos» en Historia de las diócesis españolas. Iglesias de Burgos, Osma-Soria y Santander, 20, Bernabé Bartolomé Martínez (Coord.), Madrid, 2004, pp. 73-74.

${ }^{4}$ Archivo de la Catedral de Burgos (en adelante ACB), Volumen 29, f. 358. En 1395 Benedicto XIII había mandado a los obispos de Zamora, Ávila y Sigüenza que estudiasen la petición de anexión de préstamos a la mesa capitular de Burgos, valorando como muy elevado el número de 80 beneficiados existentes en el cabildo, $c f$. ACB, Volumen 63, f. 45, 15/02/1395.
}

Hispania Sacra, LX

121, enero-junio 2008, 67-94, ISSN: 0018-215-X 
hicieron necesario el recurso a la justicia eclesiástica. Todo parece indicar que la introducción de esta dignidad no fue el fruto de una decisión voluntaria del cabildo. Nada se nos dice de las causas concretas ni de los posibles promotores de la introducción de la dignidad de la maestrescolía. Sabemos, sin embargo, que el Papa Nicolás V (1447-1455) otorgó bula de institución de la escolastría o maestrescolía a los cabildos catedralicios de Burgos y Calahorra en el año 14545 . Quizás, la férrea resistencia del cabildo burgalés a las demandas del maestrescuela debería enmarcarse en un contexto más amplio: la reacción de la corporación ante las reformas emprendidas por el Obispo Acuña (1456-1495) ${ }^{6}$.

\section{La MAestrescolía EN la CATEdRAL DE BuRgos}

Mediado el siglo XIII los cabildos catedralicios castellano-leoneses disfrutaban de un notable grado de autonomía como muestran sus prácticas en lo referente a la provisión de beneficios y el modo de gestionar sus patrimonios. Sin embargo, las dificultades económicas que tuvieron que afrontar por entonces y los agravios comparativos en los ingresos de sus miembros, crearon diferencias que trataron de corregirse desde el Pontificado ${ }^{7}$. En el contexto de una política pontificia centralizadora, el Papa Inocencio IV envió legados a las iglesias castellano-leonesas para impulsar una serie de reformas. Algunos de estos legados, como el cardenal de origen burgalés Gil Torres, elaboraron las constituciones que posteriormente se aplicaron en los cabildos catedralicios. En ellas se estipulaban los ingresos correspondientes a las dignidades, canónigos y racioneros. En todas se nombraba entre las dignidades al maestrescuela, excepto en las de Burgos (confirmación pontificia, 1252) ${ }^{8}$. En concreto, en las otorgadas a los cabildos de las catedrales de León (1224), Astorga (1228) y Ávila (1250) se detallaban las funciones propias de esta dignidad: proveer a las escuelas de un maestro que enseñe la gramática, supervisar los libros empleados en el coro y la liturgia, redactar y controlar los documentos expedidos por la institución ${ }^{9}$.

\footnotetext{
${ }^{5}$ En ambas bulas se argumenta que estos dos cabildos debían tener la dignidad de escolástico o maestrescuela como la poseían otros cabildos catedralicios del reino de Castilla para garantizar la enseñanza de los clérigos y otras personas, $c f$. Vicente Beltrán De Heredia, Bulario de la Universidad de Salamanca (1219-1549), vol. 3, Salamanca, 1967, doc. 1.152, 04/04/1454: institución de la escolastría en la Iglesia de Burgos. Y doc. 1.158, 31/12/1454: institución de la escolastría en la Catedral de Calahorra.

${ }^{6}$ Nicolás LóPez MARTíneZ, «Don Luis de Acuña, el cabildo de Burgos y la reforma (1456-1495)», en Burguense, 2 (1961), pp. 222-267.

${ }^{7}$ Peter LiNeHAN llamó la atención sobre la situación económica de los cabildos catedralicios castellanos en La Iglesia española y el Papado en el siglo XIII, Salamanca, 1975.

${ }^{8}$ Augusto Quintana PrIETo, «Constituciones capitulares de cabildos españoles del siglo XIII», en Anthologica Аппиа, 28-29 (1981-1982), pp. 517-524.

${ }^{9}$ Ibidem, pp. $495-498$, pp. $499-500$ y pp. 507-517.
} 
Desde el siglo XIII en adelante, en la documentación catedralicia burgalesa, hallamos la figura del capiscol y referencias a maestros, repetidores y bachilleres de la gramática, pero no se utiliza el término castellano maestrescuela como ocurre en otras catedrales. Puede que el capiscol, cantor o chantre, como se le denomina en otros cabildos, a cuyo cargo estaba la enseñanza de la música y la dirección del coro, asumiera durante el siglo XIII y parte del siglo XIV competencias en la enseñanza de la gramática. La situación habría presumiblemente variado desde finales del siglo XIV, pues es entonces cuando comienzan a aparecer en la documentación referencias a maestros y bachilleres de la gramática nombrados por el cabildo para enseñar y regir las escuelas ${ }^{10}$. No obstante, al hilo de la exposición del conflicto, se comprobará la presencia significativa que el capiscol tiene en los problemas relativos a la escuela de gramática. Por otra parte, si nos atenemos a las pruebas documentales aportadas por el maestrescuela en defensa de sus posiciones, la dignidad de maestrescuela como tal no fue una realidad en el cabildo burgalés hasta que fue instituida por Nicolás V (1447-1455). La bula, del 4 de abril 1454, señalaba que la persona nombrada como maestrescuela era Alfonso López de Béjar, porcionario o racionero de la Catedral de Burgos ${ }^{11}$. Más adelante veremos cómo también disfrutaba por entonces del arcedianato de Béjar en la diócesis de Plasencia.

\section{LOS PROLEGÓMENOS DEL CONFLICTO: EL MAESTRESCUELA EN BUSCA DE SU ESTATUS}

Al tiempo que Luis de Acuña era nombrado por el Papa Calixto III Obispo de Burgos (1456), tomando posesión de la sede episcopal a comienzos del siguiente año ${ }^{12}$, las Actas Capitulares o Libros de Registros comenzaron a consignar entre los habitualmente reunidos en cabildo al maestrescuela Alfonso López de Béjar. Este hecho coincidió con el inicio de dos décadas turbulentas en Burgos, debido a los enfrentamientos entre el alcaide del castillo, representante del poder real, y la ciudad. Esta buscará el favor del cabildo y del Obispo frente a los tenentes del castillo, el poderoso linaje de los Estúñiga, condes de Plasencia. El conde Alvaro de Estúñiga se alineó con los representantes de los linajes nobilia-

10 Susana Guijarro GonZÁLEZ, «Los centros de cultura urbana en el siglo XV: las escuelas de gramática castellano-leonesas», en El umbral de la Modernidad: el Mediterráneo europeo y las ciudades en tránsito de los siglos XV-XVI, José Hinojosa Montalvo y Jesús Pradells Nadal (eds.), Valencia, 1994, pp. 245-250. Y Maestros, escuelas y libros: el universo cultural de las catedrales en la Castilla medieval, Instituto Antonio Nebrija, Madrid, 2004, pp. 257-276.

11 Vicente Beltrán DE Heredia, Cartulario, Vol. 3, doc. 1.152, 04/04/1454: «Nicolaus etc. Ad futuram rei memoriam. Ex supernae providentia majestatis. Cum sicut accepimus, dilectus filius Alfonsus Lupi, perpetuus protionarius in eccl. Burgen., baccalarius in legibus...».

12 ACB, Bula de Calixto III, 12/11/1456, Volumen 63, f.3.Y toma de posesión en 04/04/1457, Lib. Reg. 19, f. 43.

Hispania Sacra, LX

121, enero-junio 2008, 67-94, ISSN: 0018-215-X 
rios que favorecían el ascenso al trono del infante Alfonso frente a su hermano el Rey Enrique IV (1425-1474). Al deseo de ecuanimidad del Obispo Acuña se oponía la realidad de los lazos de parentesco que le unían al grupo de caballeros nobles, acogidos por el conde Álvaro de Estúñiga en el castillo.

El conde y lo caballeros nobles pidieron al Obispo y al cabildo apoyo a su proyecto de derrocar a Enrique IV y elevar al trono a su hermano Alfonso $(† 1468)^{13}$. Fue precisamente a través del Obispo y los condes de Plasencia como el maestrescuela López de Béjar obtuvo una de las cartas que esgrimió ante el cabildo catedralicio burgalés para que sus demandas fuesen atendidas. Alfonso López era arcediano de Béjar, diócesis de Plasencia, como vimos, cuando fue provisto de la maestrescolía de Burgos hacia 145514. Algunos datos más permiten concretar las vinculaciones entre la Iglesia catedralicia burgalesa y las iglesias diocesanas de Plasencia y Coria. Así, el protonotario de la Iglesia de Burgos por entonces, Juan Manrique, era hermano del Obispo de Coria. El arcediano de Cáceres, Pedro de Carvajal, disfrutaba de una canonjía en Burgos que posteriormente permutó con el maestrescuela López de Béjar por los préstamos que éste último poseía en la diócesis de Plasencia. Puede asimismo adivinarse el parentesco de Pedro de Carvajal con el Obispo de Plasencia y Cardenal de Sant Angelo, Juan de Carvajal $(† 1469)^{15}$. Aunque no hallamos constancia documental de lazos de parentesco concretos o de otro tipo, estos indicios hacen pensar que en el nombramiento de Alfonso López de Béjar como maestrescuela de Burgos pudieron haber influido el Obispo y los condes de Plasencia, próximos al Obispo Acuña en algunos momentos. Por otra parte, la presencia en el cabildo burgalés de clérigos procedentes de la diócesis placentina había sido favorecida desde el episcopado de Pablo de Santamaría (1415-1435), padre del Obispo de Plasencia, Gonzalo de Santamaría (1423-1446).

Más arduo resulta conocer la postura del cabildo en la provisión del maestrescuela, pero algunos hechos ocurridos entre 1456 y 1461 revelan que la inserción de la nueva dignidad en el organigrama jerárquico capitular creó problemas. Por una parte, se constata documentalmente que el maestrescuela López de Béjar participaba en las reuniones del cabildo y, como a otras dignidades y canónigos, se le otorgaban poderes para efectuar contratos de arrenda-

\footnotetext{
13 Sobre las frecuentes tensiones entre la ciudad y los tenentes del castillo de Burgos, vid. Luis MARTíneZ GARCÍA, «El castillo de Burgos y el poder feudal (siglos XIV y XV)» en El castillo de Burgos, Burgos, 1997, pp. 151-172.

${ }^{14}$ ACB, Lib. Reg. 18, f. 262, 30/11/1469: en esta fecha los señores del cabildo reconocen que Alfonso López de Béjar había ocupado la maestrescolía pacíficamente desde hacía más de catorce años.

15 Diccionario de Historia Eclesiástica, Q. Aldea Vaquero, T. Marín Martínez y J. Vives CasTELL, (dirs.), vol. 1, Madrid, 1972, p. 347.
} 
miento de casas pertenecientes a la institución ${ }^{16}$. Incluso recibió licencia para ir a Estudio General o universidad durante un año en 145917. Por otra parte, un signo externo de la posición jerárquica de los capitulares de gran importancia, cual es la silla que ha de ocupar en el coro y su lugar en las reuniones del cabildo, estaba aún por resolver a finales de 1456.

El estatuto del coro, cuyo origen se remontaba a los tiempos del Obispo Mauricio, establecía claramente que cada beneficiado debería ocupar silla en el coro y lugar en el cabildo según la dignidad y el beneficio que disfrutaba ${ }^{18}$. Sin embargo, el maestrescuela «nuevamente nombrado», mantuvo una polémica con el Abad de San Quirce por la silla que debía ocupar. Se le adjudicó provisionalmente la situada debajo de la del abad de San Quirce ${ }^{19}$. A ello se añade que dos años más tarde, en 1458, tuvo que recordarle al cabildo que, según la bula apostólica de Nicolás IV (1447-1455) que obraba en su poder, debía anexionarse una canonjía a la dignidad de la maestrescolía. En consecuencia, le pertenecía la primera canonjía que quedase vacante ${ }^{20}$. El cabildo lo puso en duda en ese momento y lo negó. Dos años más tarde, cuando se presentó tal circunstancia, optó por seguir la práctica acostumbrada en la provisión de beneficios eclesiásticos vacantes.

No está claro que el conjunto del cabildo hubiese reconocido el estatus que la figura del maestrescuela tenía en otras catedrales coetáneas. Así, en un debate sobre la provisión de la portería de la catedral (1461), ante la intervención del maestrescuela, los racioneros replicaron que él no tenía «ni voz, ni voto» ${ }^{21}$. Es

${ }^{16}$ ACB, Libro 2, f. 18, 16/07/1459: le otorgan poder para que revise el contrato a censo de unas casas. ACB, Libro 2, f. 157, 17/10/1464: le otorgan poder junto a otros canónigos para que den a censo al arcediano de Treviño unas casas. ACB, Libro 1, ff. 140-141, 07/10/1467: se otorga poder al capiscol, al maestrescuela y a un canónigo para que concierten con el arcediano de Lara el censo de unas heredades.

${ }_{17}$ ACB, Lib. Reg. 16, ff. 121-121v: Alfonso López de Béjar, maestrescuela, solicita licencia para ir a Estudio y que se le sigua considerando residente en su prebenda. Pide, al mismo tiempo, que se le conceda gracia de ayuda durante este tiempo. Esto último se discute, decidiéndose que se le darán ocho mil maravedíes, la cantidad anual establecida para los van a un Estudio General o escuela.

${ }_{18}$ ACB, Libro 63, f. 760v: «que los beneficiados guarden sus escalos cada uno en su lugar, segund la dignidad e el beneficio que tienen, ay en el choro como en el cabildo, segund es ordenado por el Obispo Mauriz...».

${ }^{19}$ ACB, Lib. Reg. 14, ff. 243v-244, 03/11/1456.

${ }^{20}$ ACB, Lib. Reg. 16, f. 67v, 09/12/1458: «e luego se levantó el señor maestrescuela e diso que quanto avía / una bulla por la qual nuestro Santo Padre anexa a su dignidad de la maestrescolía/ la primera calongía que veniese. E creo que me pertenesçe esta por ende................sy después demandaren mi derecho no lo aviades a ninguno e los dichos señores diseron que esto non tenían que faser».

${ }^{21}$ ACB, Lib. Reg. 16, ff. 233, 27/02/1461: «...... e començado el dicho señor maestrescuela a fablar le fue dicho por......e por otros canónigos que non tenía vos e que era racionero/e que non devía dar su voto». En un acuerdo del cabildo catedralicio de 1439 se había establecido que sólo podrían participar con voz en las reuniones del mismo los racioneros presbíteros, $c f$. ACB, Libro 36, f. 284, 31/07/1439.

Hispania Sacra, LX

121, enero-junio 2008, 67-94, ISSN: 0018-215-X 
cierto que López de Béjar era racionero cuando fue instituida la maestrescolía y los racioneros tenían restringida su participación en las reuniones capitulares. Pero cabría esperar que se le hubiese reconocido su nueva condición de dignidad y canónigo, pues la bula fundacional de la maestrescolía establecía la anexión de una canonjía a la misma. Tampoco se le permitió votar en la provisión de una capellanía, anteponiendo su condición de racionero a la de dignidad que ya disfrutaba en $1462^{22}$. Otros datos confirman, sin embargo, su rango de dignidad catedralicia. En esos momentos, el maestrescuela era uno de los denominados «jueces de las cuatro témporas» que los capitulares elegían entre sus miembros, dignidades y canónigos, periódicamente, para dirimir en asuntos tocantes a la jurisdicción del cabildo ${ }^{23}$.

Lo que sí resulta evidente es que la provisión de la canonjía vacante en 1461 fue el detonante de un conflicto latente. Primero, quedó vacante la canonjía de Juan de Velasco, que desde hacía seis años ocupaba el clérigo de Segovia, Juan Arias. No olvidemos que el Obispo Acuña había llegado a Burgos tras ocupar la sede episcopal de Segovia y que favorecer a familiares y criados en la provisión de beneficios eclesiásticos fue algo habitual de los prelados. Después, el maestrescuela reclamó la posesión de esta canonjía en virtud de la citada bula y el consiguiente proceso apostólico sobre ella formulado, pero le fue denegada. El cabildo alegó que disponía de letras inhibitorias que le impedían atender su petición ${ }^{24}$.

Tampoco aceptó la reclamación del maestrescuela cuando se proveyó de la canonjía vacante al licenciado Juan de Lucena. El maestrescuela llegó a apelar esta provisión en el acto de recepción del nuevo canónigo en el coro ${ }^{25}$. Es posible que la condición de «familiar del Papa» de Juan de Lucena en 1461 dejase poco margen al cabildo a la hora de elegir candidato ${ }^{26}$. De hecho, los capitulares argumentaron que el candidato Lucena poseía la correspondiente letra apostólica de concesión de gracia de un beneficio apostólico en la Iglesia de Burgos. Como sede exenta, directamente dependiente de Roma, el clero de esta diócesis estaba sujeto a la obediencia al Papa. Pero no hay que olvidar que el cabildo podía favorecer la obtención de letras apostólicas de expectativa de beneficio eclesiástico para sus

${ }^{22}$ ACB, Lib. Reg. 17, ff. 7v-8, 29/01/1462.

23 ACB, Lib. Reg. 18, ff. 53-54v, 18/09/1467: aún aparece como uno de los jueces de las cuatro témporas

${ }^{24}$ ACB, Lib. Reg. 16, ff. 252v-253, 06/05/1461. Finalmente, f. 253v «por ruego de algunos señores del cabildo diso que se partía del requerimiento que había hecho de la canonjía de Juan Arias. ACB, Lib. Reg. 16, f. 255, 13/05/1461: letras inhibitorias.

${ }^{25}$ ACB, Lib. Reg. 16, f. 274v, 21/08/1461.

26 Vicente Beltrán DE Heredia, Cartulario, vol. 3, doc. 1201, 03/11/1461. Se concede a Juan de Lucena, licenciado en decretos, que la condición de familiar del Pontífice después de que haya terminado se prorrogue todavía por un año. 
candidatos. Siguiendo el estatuto de alternancia, la elección la realizaba unas veces el Obispo, otras el cabildo y algunas veces, ambos conjuntamente. La letra apostólica de gracia del Papa otorgada al licenciado Juan de Lucena venía acompañada del preceptivo proceso apostólico, firmado por Juan Díaz de Coca, deán de Burgos y auditor del Sacro Palacio. Sin duda, el cabildo burgalés contaba con personas que velaban por sus intereses en la Corte romana.

\section{LAS REIVINDICACIONES DEL MAESTRESCUELA Y EL DESARROLLO DEL CONFLICTO}

Después del incidente por la concesión de la canonjía al licenciado Juan de Lucena en 1461, el protagonismo del maestrescuela fue discreto hasta los años finales de la década. Quizás estuviera ausente en algún tiempo a causa de la licencia para estudios que había solicitado. En 1467 pidió licencia para permutar la canonjía que dejó vacante Pedro de Carvajal, arcediano de Cáceres y canónigo de Burgos, pero hasta una década después no hay constancia de su provisión ${ }^{27}$. Desde entonces y hasta 1472, la tensión entre el maestrescuela y el cabildo, especialmente con algunos miembros, fue en aumento. Hubo una serie de episodios relacionados con tres conflicto principales: litigio con el arcediano de Palenzuela a causa de unos préstamos anexos a la canonjía que solicitaba, administración de la escuela de gramática y provisión de su cátedra de la misma y reclamación de su lugar en el coro.

\section{Los préstamos del arcediano de Palenzuela}

La demanda por parte del maestrescuela López de Béjar de la canonjía y préstamos que quedaron vacantes tras la muerte de Juan Velasco, ocupada por un clérigo de Segovia desde hacía seis años, abrió una agria polémica entre el maestrescuela y el arcediano de Palenzuela. Este último se había hecho con los préstamos pertenecientes a esta canonjía mediante una permuta con el Obispo de Segovia. Los préstamos eran rentas derivadas de beneficios eclesiásticos que tenían la ventaja de no exigir la residencia de quien los disfrutaba en la iglesia a la que estaban asignados. En 1467, el maestrescuela reclamó al Obispo de Segovia el reconocimiento de la suma de préstamos anexos a la disputada canonjía, a lo cual, este respondió que demostrase sus derechos ${ }^{28}$. Tanto en Segovia,

${ }^{27}$ ACB, Lib. Reg. 18, f. 6, 18/02/1467.

${ }^{28}$ ACB, Lib. Reg.18, f. 12, 13/03/1467: López de Béjar pidió licencia al cabildo para desplazarse a Segovia, exigiendo que se le respetasen las distribuciones cotidianas que se repartían por asistencia al coro («que se le punte») durante su ausencia. Después de una discusión los capitulares le concedieron veinticinco días para realizar la gestión.

Hispania Sacra, LX

121, enero-junio 2008, 67-94, ISSN: 0018-215-X 
(1467) como en Burgos (1468), apoyó su reclamación en la bula de Nicolás V (1447-1455) y el proceso formulado sobre la misma, según el cual, había sido proveído de la canonjía que vacó por muerte de Juan de Velasco. El maestrescuela dijo, además, tener carta de Roma para tomar posesión de los referidos préstamos $^{29}$.

Al mismo tiempo que esto sucedía, como indicaremos más adelante, obtuvo cartas pontificias para despojar de su posición al bachiller que se hallaba al cargo de las escuelas de gramática. Se iniciaba así la fase aguda del conflicto que desembocaría en una cascada de excomuniones recíprocas a partir de noviembre de 1468. El cabildo, tan celoso en otras ocasiones de su privilegio de exención, que les hacía depender directamente de Roma con la obediencia que ello conllevaba, se aferró a sus «derechos e costumbres de tiempo inmemorial» frente a las «innovaciones» que pretendía hacer el maestrescuela; y recurrió a argumentos de tipo legal para negar la validez de los documentos pontificios presentados por el maestrescuela. En el derecho romano-canónico bajomedieval la presentación de documentos falsos en un proceso era duramente penada, aunque en este caso se habla de documentos irregulares ${ }^{30}$. El cabildo reconoció en varias ocasiones al maestrescuela el derecho a perseguir sus causas a través de la justicia eclesiástica, pero le reprochó que, sin informar antes a la institución, hubiese utilizado a personas de peso externas para obtener esos documentos.

El primer obstáculo legal que el maestrescuela encontró en el cabildo fue el rechazo del tesorero, la dignidad que había elegido como subejecutor de la bula apostólica de Nicolás V. El tesorero se negó a ser subejecutor amparándose en una regla de cancillería del Papa Calixto III (1455-1458). Calixto III había revocado la bula de anexión de préstamos a la maestrescolía de su antecesor. Ante esta actitud, el maestrescuela promovió carta de excomunión contra el tesorero. Este se consideró gravemente injuriado y presentó a su vez una bula papal y proceso sobre ella hecho, según la cual ningún juez apostólico ni ordinario podía proceder contra él ${ }^{31}$. Además, exigió al cabildo que terciase en su problema con el maestrescuela ${ }^{32}$. La respuesta del cabildo marcó la posición que iría tomando posteriormente en defensa de sus estatutos y jurisdicción.

En primer lugar, negó la validez de las cartas presentadas por el maestrescuela sobre la posesión de préstamos, aduciendo que habían sido otorgadas por un juez, el tesorero y provisor de Plasencia, sin jurisdicción en Burgos y que

\footnotetext{
${ }^{29}$ ACB, Lib. Reg. 18, ff. 135v-136, 01/08/1468.

${ }^{30}$ Remedios Morán MARTín, Historia del derecho privado, penal y procesal, Madrid, 2002, p. 442.

${ }^{31}$ ACB, Lib. Reg. 18, ff. 144-145v y f. 148, 12/08/1468.

${ }^{32}$ ACB, Lib. Reg. 18, f. 156, 12/08/1468: el maestrescuela responderá que éste no es asunto a tratar en cabildo porque él está obligado a aceptar el oficio de subejecutor. Por tanto, apelaba su decisión de no aceptar.
} 
habían ya prescrito ${ }^{33}$. En las causas planteadas ante la Santa Sede, lo habitual era que el Papa nombrase jueces delegados para entender en ellas ${ }^{34}$. Resulta extraño que el cabildo negase a uno de estos jueces la jurisdicción que implícitamente se le reconoce con el nombramiento pontificio.

En segundo lugar, el cabildo burgalés defendió el criterio de antigüedad: tanto en lo relativo a la posesión de los préstamos como a la titularidad de la escuela de gramática, interpretaron que el maestrescuela pretendía despojar de su posesión a personas que acumulaban años en el cargo o en el disfrute de unos derechos ${ }^{35}$. En última instancia, reiteraron una y otra vez los capitulares, el maestrescuela debía respetar el juramento de guardar los estatutos y costumbres de la Iglesia de Burgos, hecho al ser recibido en la institución.

El mayor afán de la corporación era mantener la paz interna y evitar que los problemas entre sus miembros traspasasen los muros de la Catedral. Por ello, apremiaron al arcediano de Palenzuela y al maestrescuela López de Béjar a alcanzar una concordia y reprobaron los actos llevados a cabo por ambos para hacer efectiva la posesión de los disputados préstamos. Se les acusó de recurrir al alcalde del castillo para ejecutar esos actos. Esto, dijeron, iba contra el estatuto capitular que prohibía a un beneficiado procurar favores contra otro beneficia$\mathrm{do}^{36}$. Les instaron a que «ninguno de ellos faga cosa de fecho e que por tinta e papel sigua cada uno su derecho, nin por fuerça o violencia, nin por manera de escándalo sopena de çien doblas a cada uno para la mesa capitular e un año de reçesit (retención de sus prebendas y de las distribuciones cotidianas) ${ }^{37}$ ». Nom-

${ }_{33}$ ACB, Lib. Reg. 18, f. 149v, 12/08/1468: «e luego el arcediano de Lara, de mandado de los señores del cabildo,/ diso que el señor maestrescuela en efecto que ya sabía commo los señores del/ cabildo le avían mandado venir al cabildo para fablar con él/ cerca destos fechos por el yntentados. E que ya sabía commo por la graçia / de Dios este cabildo siempre fue e será de siempre ser / obediente a los mandamientos apostólicos. E contra protestaçión le relató e/ diso las cosas que avía fecho nin guardado la orden e forma./ Otrosy que, quanto a las cartas que avía fecho leer el contenido sobre la posesión/ de los préstamos e sobre la calongía de la escuela de gramática, que bien/ sabía él que el dicho jues que las diera non tenía nin tobo jurisdiçión/ e eran extingidas de derecho por muchas cabsas e rasones que eran notorias./ Era cabsa para escandaliçar pero non cosa que fesiese fruto, ça para algunos/ señores tenían dellas e se obligaba qualquier mal e dampno que por esta cabsa veniese contra ellos, que los saca a salvo. E,por ende, que le/ exortaba a Dios que se partiese destas cosas, sy algund derecho/ tenía, lo seguiese en el orden e forma que Dios quiere/ e non quiera dar lugar a otros inconvenientes».

${ }^{34}$ Antonio GARCÍA Y GARCÍA, «El proceso canónico medieval en la documentación medieval leonesa», en Iglesia, sociedad y derecho, 3, Salamanca, 2000. p. 257.

35 ACB, Lib. Reg. 18, f. 153, 12/08/1468: «quanto a lo de la materia de los préstamos, que pues asy mesmo es notorio/ que el señor arcediano de Palençuela e sus anteçesores han poseydo pacíficamente/ los dichos préstamos por espaçio de trese o de quatorse años, que le amonestan/ ruegan, encargan e mandan que no se entrometa en le molestar en la/ posesión, pues esto sería e es manifiesto cosa de fuerça e violencia/ a la qual el reverendo señor Obispo e ellos son obligados de derecho de mandar (litigar)/. E quanto a la persecuçión de la propiedad que la persigua ante quien e commo/ deva»

${ }^{36}$ ACB, Lib. Reg. 18, f. 154, 12/08/1468.

${ }^{37}$ ACB, Lib. Reg. 18, f. 154v, 12/08/1468.

Hispania Sacra, LX

121, enero-junio 2008, 67-94, ISSN: 0018-215-X 
braron a cuatro capitulares para que se reuniesen con el alcalde y se informasen de lo sucedido, y propusieron un letrado que estudiase el caso.

El maestrescuela interpretó estos movimientos como una clara voluntad por parte del cabildo de entorpecer su derecho a obtener justicia y de eludir la jurisdicción del Obispo y del Papa. En virtud de las letras apostólicas que le había otorgado el Papa, bien podía despojar al arcediano de Palenzuela de los préstamos. Así, adoptando una postura de fuerza, desafió a los capitulares a que le demandasen por vía judicial. Esta manifestación del maestrescuela fue interpretada por el cabildo como prueba de su voluntad «de los indignar e enojar» 38 .

En los cuatro últimos meses de 1468 continuaron la polémica sobre la suma de préstamos, cuya titularidad se arrogaba el maestrescuela, y la búsqueda de posibles soluciones. Se trataba de los préstamos de Soto, Cebrecos, Villadiego y Santa Gadea. Su reclamación de los mismos no sólo enfrentaba al maestrescuela con el arcediano de Palenzuela sino también con otros miembros del cabildo que tenían arrendados los préstamos. Ante las acciones emprendidas por el maestrescuela contra estos arrendadores, el cabildo le recordó que era competencia de la institución el arrendamiento de los frutos de estos préstamos ${ }^{39}$. A esta situación, habría que añadir las alegaciones interpuestas por el maestrescuela a la provisión de una canonjía a favor de Pedro Fernández, valoradas por los capitulares como un perjuicio a la Iglesia ${ }^{40}$.

\section{La exteriorización del conflicto sobre los préstamos}

En septiembre de 1468, la disputa entre el arcediano de Palenzuela y el maestrescuela afectaba ya seriamente a la imagen de convivencia pacífica que deseaba transmitir la institución. No se hablaban ni se trataban, lo cual iba en detrimento del servicio al coro y otras ceremonias. Cabildo y Obispo de Burgos buscaron un acuerdo entre las partes y les instaron a hablarse mientras perseguían sus respectivas causas ${ }^{41}$.

\footnotetext{
${ }^{38}$ ACB, Lib. Reg. 18, f. 155v, 12/08/1468: «e el dicho señor maestrescuela diso que se maravillava dellos en non/ le querer desar seguir su justicia, que por quitar las jurisdiçión/ a nuestro señor el Papa e asy mesmo al Obispo. E que por ende que pues nuestro/ señor el Papa le dava poder por sus letras para tomar la posesion que lo/ avía bien podido faser despojar asy al dicho bachiller como / al dicho señor arcediano, e que le demandasen, que el les satisfara por su derecho e que al señor arcediano devian castigar por aver ydo contra el estatuto. E fuele respondido por el señor maestro, en nombre de los señores, que se maravillava del dicho/ señor maestrescuela en desir que ellos se entremetieran a perturbar la jurisdiçión/ de nuestro señor el Papa e al señor obispo, e que bien paresçía que agora/ avía mas voluntad delos enojar e de indignar..».

${ }^{39}$ ACB, Lib. Reg. 18, f. 139v, 12/08/1468:

${ }^{40}$ ACB, Lib. Reg. 18, f. 162, 14/09/1468.

${ }^{41}$ ACB, Lib. Reg. 18, f. 159v, 13/09/1468.
} 
El maestrescuela propuso al arcediano de Palenzuela un acuerdo: desistiría de sus propósitos si el segundo dejaba el préstamo de Cebrecos. El arcediano se negó y le ofreció tres mil maravedíes para sufragar los gastos en costas que esta causa le había originado. Fue entonces cuando la justicia del Obispo, a través del vicario, medió entre ambos, pidiendo al arcediano que le entregase cinco mil maravedíes al maestrescuela y, al mismo tiempo, al cabildo que hiciese su propuesta para lograr la paz entre los dos contendientes. El cabildo ofreció al maestrescuela ocho o diez mil maravedíes en préstamos y hasta catorce mil para compensar los gastos en costas y lo que perdió al excluirle de las distribuciones cotidianas ${ }^{42}$.

Este podría haber sido el final de la contienda sobre los préstamos, pero las cartas de excomunión que el maestrescuela había promovido contra algunos señores del cabildo agravaron su conflicto con el mismo ${ }^{43}$. En octubre de 1468, el maestrescuela entró en litigio con otros dos capitulares, Diego Sánchez y Juan Alonso, arrendatarios del préstamo de Villadiego. Ambos se querellaron contra él porque les perturbaba en relación con las rentas del préstamo ${ }^{44}$. En los dos meses siguientes, las cartas de excomunión enturbiaron por completo la vida cotidiana en las dependencias catedralicias y sacaron al exterior el conflicto entre el maestrescuela y el cabildo.

A comienzos de noviembre, el maestrescuela presentó las cartas de excomunión del arcediano de Palenzuela, del Abad de San Quirce, del canónigo Pedro Fernández y de Juan Fernández de Villaldemiro. Las cartas de excomunión fueron otorgadas por el tesorero y provisor de Plasencia, que había sido también juez ejecutor de la bula de institución de la maestrescolía. A Pedro Fernández se le excomulgaba porque perturbaba al maestrescuela en su intento de poseer la canonjía anexa a la maestrescolía. Y a Juan Fernández de Villaldemiro por participar en la contienda que seguía con el arcediano de Palenzuela acerca de los préstamos ${ }^{45}$.

Ambos capitulares reaccionaron no reconociendo la autoridad del juez apostólico y, según el maestrescuela López de Béjar, lanzando palabras injuriosas contra su persona y «desiendo mal del jues e del linaje del señor Cardenal», Juan de Carvajal, Cardenal de Sant Angelo ${ }^{46}$. Proferir palabras difamatorias

${ }^{42}$ ACB, Lib. Reg. 18, ff. 162-162v, 14/09/1468.

43 ACB, Lib. Reg. 18, f. 162v, 14/09/1468: Se requirió al provisor del cabildo que presentase las cartas de excomunión a varios señores que debían declarar ante el juez apostólico, ejecutor de las citadas cartas, el tesorero y provisor de Plasencia.

${ }^{44}$ ACB, Lib. Reg. 18, ff. 164v-165, 01/10/1468: al dejar vacante el préstamo estos dos señores debían satisfacer al cabildo una cantidad sobre las rentas de dicho año y la mitad del venidero, como era preceptivo de acuerdo con el «estatuto de año y medio» cuando quedaban los préstamos vacantes hasta su nueva provisión. El cabildo determinó que el maestrescuela era el deudor principal de esta cantidad.

${ }^{45}$ ACB, Lib. Reg. 18, f. 173v, 03/11/1468.

46 Idem, f. $173 \mathrm{v}$. 
contra personas que ocupaban cargos eclesiásticos constituía un delito que podría ser penado con inhabilitación para el oficio ${ }^{47}$. El maestrescuela exigió al cabildo que estos canónigos fuesen apartados de la Catedral por estar ahora excomulgados. El cabildo, por su parte, requirió al maestrescuela la presentación de todas las cartas, escritos y bulas que poseía para ser examinados por los capitulares letrados.

Ante la evidencia de que se permitía a los excomulgados continuar entrando en el coro, pidió el maestrescuela permiso para recibir las distribuciones cotidianas, «ser puntado», sin asistir a las horas canónicas, pues consideraba esta situación irregular.

Finalizado el examen de las escrituras aportadas por el maestrescuela, se falló que en las cartas no venía inserto mandato apostólico y que el mencionado juez no tenía jurisdicción en Burgos ${ }^{48}$. Nuevamente, recurrieron a invalidar los documentos presentados, alegando esta vez la ausencia del mandato apostólico de nombramiento de juez, para frenar la ejecución de las sentencias en ellos contenidas. De inmediato, «dado el gran escándalo que fiso esta carta contra nosotros» se alzan voces que piden que sea castigado «e que se diese algund escarmiento al maestrescuela por aver fecho las cosas que avia fecho» ${ }^{49}$.

Injuria será el delito que repetidamente se le impute al maestrescuela a partir de ahora. Sobre todo, la gran injuria que decían cometió al tomar testimonio a los excomulgados durante la celebración de las horas para escándalo del pueblo presente ${ }^{50}$.

La fama del cabildo como garante de la institución estaba en peligro por lo que pasaron a la aplicación de castigos sin más dilaciones: pago de ocho mil maravedíes y retirada las rentas derivadas de sus prebendas, destinadas en parte a sufragar los gastos del proceso del arcediano de Palenzuela contra él. Pero lo más deshonroso, pues afectaba a su posición jerárquica y reputación, fue que, debido a su contumacia le dieron por «adocenado», es decir, sin mérito o valor. Como hacía habitualmente, solicitó el maestrescuela López de Béjar copia escrita de todas las comunicaciones que se le hiciesen ${ }^{51}$.

47 Jacqueline HoAREAU-Dodinau, Dieu et le Roi. La répression du blasphéme et de l'injure au Roi à la fin du Moyen Age, Cahiers de 1'Institut d'Anthropologie à la fin du Moyen Age, Limoges, 2002, pp. 11-12.

48 ACB, Lib. Reg. 18, ff. 174-174v, 03/11/1468: « e por ellos fue tratado e fablado e porque otros señores del cabildo/ letrados diseron lo semejante, deliberaron que por esta carta que el dicho/ señor maestrescuela avía mostrado que non devían ser evitados estos/ canónigos nin alguno dellos. E asy mesmo todos acordaron que, / segund esto e el gran escándalo que fiso esta carta contra nosotros, que devía ser/ castigado e que otro día se ayunten a cabildo e entiendan en ello».

${ }^{49}$ ACB, Lib. Reg. 18, f. 175, 04/11/1468.

${ }^{50}$ ACB, Lib. Reg. 18, ff. 175v-176, 04/11/1468.

51 ACB, Lib. Reg. 18, ff. 176v-177, 04/11/1468. 
La difusión de los hechos continuaba preocupando a los miembros del cabildo. El tesorero manifestó que «las cosas eran tan notorias en esta çibdad destas cartas, que sy ellos están desfamados entre los legos disiendo resçebir a los que desien descomulgados que le pareçia que se enmendasen». Para que la verdad fuese conocida, propuso llamar a letrados que examinasen las cartas y procesos presentados por el maestrescuela. Acudieron tres y se requirió la presencia del maestrescuela para que entregase los documentos. Este anunció que presentaría traslados de los mismos ${ }^{52}$.

Una vez más, hizo relación y leyó las cartas de excomunión contra Pedro Fernández de Villaldemiro, Pedro Rodríguez, el abad de San Quirce y el arcediano de Palenzuela por los asuntos relacionados con la canonjía y préstamos de la maestrescolía y por la cátedra de gramática ${ }^{53}$. Los letrados determinaron finalmente que las bulas de institución de la maestrescolía y de anexión de préstamos a la misma, de acuerdo con las reglas de cancillería del Papa Calixto III, eran verdaderas; y que los procesos incoados sobre la anexión de los préstamos y canonjía carecían de jurisdicción ${ }^{54}$. En el cabildo del día siguiente el maestrescuela y Juan Fernández de Villaldemiro se acusaron mutuamente de injurias. El segundo, acusó, además, al maestrescuela de mentir, delito considerado grave ${ }^{55}$. Se delegó en el protonotario y en otro miembro del cabildo para que restableciera la concordia y fijara las penas entre los enfrentados ${ }^{56}$.

52 ACB, Lib. Reg. 18, ff. 182-183v, 14/11/1468: «en conclusión acordaron, asy el señor provisor como los vicarios e todos/ los señores del cabildo, que se llamen todos los letrados, asy de la iglesia commo/ dela çibdad. E que sobre sus juramentos e en sus consçiencias sean mostrados/ ante ellos todos los procesos e cartas e escriptos que el señor maestrescuela quisiere mostrar en guarda de su derecho por sy estos señores devien ser onrrados./ E oydo e visto su parecer, sy fallasen que non devien ser onrrados, que/ este señor maestrescuela tanto ha insistido en no querer rogar cosa de lo que/ han rogado, dicho e requerido los injuriados, que sea gravemente/ penado e desterrado del cabildo e iglesia por algund largo / tiempo. E le tomen çiertos yantares por que a él e a otros sea escarmiento/ e después de mucho platicado por todos acordaron que luego sean llamados/ los letrados ally ante ellos, para les rogar que vengan a la/ nona e descargando sus consçiencias que digan su parescer».

${ }^{53}$ ACB, Lib. Reg. 18, ff. 183v-184v, 14/11/1468

54 ACB, Lib. Reg. 18, f. 185, 15/11/1468: «e vistas las bullas de la anesión e proçesos fechos por los ejecutores/, a pedimento del escolástico, asy de la bulla principal dela maestrescolía/, commo del anexo dada sobre ella, e examinando todo con diligençia,/ paresçe nos que, segund la regla de cançellería del Papa Calixto de bien/aventurada memoria, sy aquella es verdadera que los proçesos fechos/ sobre los prestamos e calongía, asy como fechos por/ presentes, que fundamentalmente caresçen de jurisdiçión. E por que/ esto nos paresçe ser asy verdad de derecho, en cargo de nuestras consçiencias,/ firmamos aquí nuestros nombres, fecho a XV de nobiembre de sesenta e ocho/ gonçalo... bachiller, didacus de miranda, licenciado, Joannes de la Torre, bachiller de padrones, gonçalo de torres.»

55 ACB, Lib. Reg. 18, f. 185v, 16/11/1468.

${ }^{56}$ ACB, Lib. Reg. 18, f. 187, 16/11/1468: tres mil maravedíes y doce días en casa sin ser puntado para las distribuciones cotidianas para Juan Fernández de Villaldemiro. Y dos mil maravedís y ocho días en su casa sin ser puntado para el maestrescuela.

Hispania Sacra, LX

121, enero-junio 2008, 67-94, ISSN: 0018-215-X 


\section{La penalización del maestrescuela}

En el último mes y medio de 1468 se prepararon y comenzaron a ejecutarse medidas procesales y penales contra el maestrescuela. Una vez fijada la nulidad y revocación de los procesos promovidos contra el cabildo por él y, vista su voluntad de continuar con sus propósitos, acordaron llevar el caso a la Corte de Roma y, si fuese necesario, a los tribunales en Castilla. Las costas que esto generase correrían a cargo de la prebenda del maestrescuela. Enviaron mensajeros a Roma y al Obispo de Plasencia ${ }^{57}$.

Otro suceso, del que hace relación el arcediano de Palenzuela, vino a estrechar el cerco sobre el maestrescuela. Juan Fernández de Villaldemiro, como juez comisario del provisor apostólico del arcediano, había leído una carta denunciatoria de excomunión al maestrescuela en el coro de la Iglesia. Informado el provisor, decidió conceder la absolución al maestrescuela puesto que no le constaba que estuviese excomulgado. El arcediano de Palenzuela apeló esta absolución y se llamó a letrados del cabildo para que examinasen este proceso. Los letrados determinaron que Juan Fernández de Villaldemiro tenía jurisdicción por ser juez comisario del provisor apostólico y que el proceso era legítimo. Ante la posibilidad de que el maestrescuela presentase letras inhibitorias en este proceso, se recordó que todos los procesos en su poder habían sido revocados y que el juez ejecutor, tesorero de Plasencia, no podía extender su jurisdicción a Burgos. La condición de excomulgado del maestrescuela permitía al cabildo alejarlo de la Catedral y ordenar que fuera retenido en su casa. En caso de que intentase entrar en el coro durante la celebración de las horas canónicas, debía ser detenido y llevado preso a la cárcel de la ciudad, «el comunal» ${ }^{58}$.

Quedaba aún por neutralizar la reacción de los oficiales de la Iglesia de Plasencia ante la deriva que había tomado el conflicto. El mensajero enviado a Plasencia volvió con tres cartas de miembros de aquel cabildo. Una de ellas, la del tesorero y provisor de aquella catedral, que fue juez ejecutor de las discutidas bulas y procesos del maestrescuela. En las cartas se mostraba su disposición a entenderse con la Iglesia de Burgos y su Obispo ${ }^{59}$.

Sin duda, la diplomacia dio sus frutos pues a primeros de 1469 el tesorero y provisor de Plasencia revocó todos los procesos y cartas anteriores ${ }^{60}$. Por otro

${ }^{57}$ ACB, Lib. Reg. 18, f. 186, 16/11/1468.

58 ACB, Lib. Reg. 18, ff. 188-188v, 21/11/1468.

59 ACB, Lib. Reg. 18, f. 194v, 17/12/1468: «por las quales en efecto paresçe que todos se ofreçieron a faser lo/ que compliese a honra y serviçio desta santa yglesia e del señor Obispo, e de todos los/ señores del cabildo. E,como venia fecho todo lo que les avía cumplido/, pagado del cabildo mas largo faría relaçion el dicho Pero Rodrigues».

${ }^{60}$ ACB, Lib. Reg. 18, f. 194v, 16/01/1469. 
lado, el Obispo de Burgos, informado del desarrollo del conflicto entre el arcediano de Palenzuela y el maestrescuela, sacó a colación uno de los caballos de batalla de su programa reformador: el exceso en las competencias jurisdiccionales que se habían arrogado los arcedianos en el pasado frente a las competencias del Obispo, apoyándose en la sujeción directa de la diócesis al Pontificado romano. Esto era especialmente cierto en los casos de los arcedianos de Lara, Treviño y Palenzuela. Al último, el obispo Acuña recordó esta circunstancia en relación con unas cartas que había otorgado ${ }^{61}$.

Las reivindicaciones del maestrescuela continuaron ocupando buena parte de los debates entre los capitulares. A comienzos de 1469, el maestrescuela volvió a presentar al cabildo, a través de su capellán y de su sobrino, las cartas que había obtenido del tesorero de Plasencia. Vista la contumacia del maestrescuela, el cabildo reiteró la ejecución de las penas que le habían sido impuestas, incluido el embargo de sus bienes y su encierro en la prisión del comunal durante quince días. De este hecho, fueron informados el Obispo de Burgos y los oficiales de Plasencia ${ }^{62}$.

Titular de la jurisdicción diocesana en última instancia, correspondía al Obispo la asignación de penas de prisión. Fue quizá esta medida extrema, la que llevó al maestrescuela mes y medio después a solicitar una concordia con el arcediano de Palenzuela, en la que mediaron varios miembros delegados por el cabildo ${ }^{63}$. El maestrescuela pidió que se rebajasen las penas impuestas y se le devolviesen los frutos de rentas y distribuciones cotidianas que se le habían suprimido. Los capitulares delegados le impusieron tres condiciones: desistir de su reclamación de la administración de la escuela de gramática y la provisión del maestro de gramática, cesar de perturbar a los poseedores de la canonjía y préstamos que reivindicaba y renunciar a tener otra canonjía o prebenda anexa a su dignidad, además de la que ya tenía. Aceptó las tres condiciones y, ante el vicario del Obispo, juró cumplirlas y no ir en contra en un juicio, ni pedir absolución o relajación de estas imposiciones ante el vicario. Pidió también que se le absolviese de la sentencia de excomunión, si hubiere incurrido en ella ${ }^{64}$.

A fines de 1469 aún no había logrado los frutos de sus prebendas reclamados. Los solicitó por justicia y no como una concesión graciosa. En cambio, le reconocieron su posesión de la maestrescolía, en la que dijeron llevaba catorce años. Pero, dado que las bulas y procesos que poseía habían expirado tras el fallecimiento del Papa Calixto III, le requirieron que demostrase «por legítimos

\footnotetext{
61 ACB, Lib. Reg. 18, f. 194v, 17/12/1468.

${ }^{62}$ ACB, Lib. Reg. 18, f. 201v, 16/01/1469.

${ }^{63}$ ACB, Lib. Reg. 18, f. 212v, 02/03/1469.

${ }^{64}$ ACB, Lib. Reg. 18, f. 212v-215, 03/03/1469.
}

Hispania Sacra, LX

121, enero-junio 2008, 67-94, ISSN: 0018-215-X 
documentos la fama, manera e saberes como dise que deve ser resçebido» ${ }^{65}$. Asimismo, introdujo en el cabildo a su sobrino Pedro Fernández de Béjar, el cual fue proveído de la canonjía a la que había renunciado Juan Rodríguez de Camargo, abad de Castro y maestrescuela de Salamanca ${ }^{66}$.

Hecha esta concordia, sin embargo el conflicto estaba aún lejos de concluir. Se reabrió el enfrentamiento en enero de 1470. El maestrescuela fue acusado de romper el juramento hecho tras la concordia de perseguir su causa sólo en la Corte de Roma, respetar los estatutos y «non façer innovaciones». Por tales, entendían que hubiese presentado ante el provisor proceso y sentencia contra el arcediano para privarle de sus beneficios, lo cual iba contra la costumbre de no impetrar beneficios de beneficiado alguno. De nuevo, no reconocieron la jurisdicción del tesorero de Plasencia, juez que había dado las cartas. Consideraron «estas innovaciones agora por él fechas en grand injuria desta iglesia» y que no pretendían más que «la indignidad de la iglesia». Por tanto, ante su «rebeldía y contumacia» ordenaron a los puntadores y mayordomos que le pusiesen en reçesit (retención de lo que le corresponde de sus prebendas y distribuciones cotidianas). Al tesorero de Plasencia que actuó como juez ejecutor se le abrió proceso judicial y se permitió al arcediano de Palenzuela recibir sus distribuciones cotidianas mientras iba a Roma a perseguir su defensa ${ }^{67}$. El maestrescuela pidió estas mismas condiciones para defender sus derechos; obtuvo gracia de cuatro meses par ir a Roma, recibiendo sus beneficios desde el día que fue puesto en reçesit hasta mayo ${ }^{68}$.

\section{La provisión de la cátedra de Gramática y la administración de las escuelas}

En agosto de 1468, mientras el maestrescuela reclamaba los préstamos del arcediano de Palenzuela, se abrió un segundo frente en el prolongado conflicto con la institución catedralicia. El maestro de la gramática, Juan González de Santamaría, informó al cabildo de «un traslado de una carta que agora nuevamente el maestrescuela le avía fecho leer del provisor del Obispo de Plaçencia, commo jues executor». En ella, el maestrescuela reclamaba la pertenencia a su dignidad de la administración de la escuela de gramática de la ciudad y de los frutos y rentas anexos a la misma. En caso de que el maestro Santamaría no abandonase la administración de la escuela en el plazo de seis días, se promulgaría sentencia de excomunión contra él ${ }^{69}$. Esgrimiendo la antigüedad, el maestro recordó que hacía veintiocho años que tenía a su cargo la escuela de gramática.

\footnotetext{
${ }^{65}$ ACB, Lib. Reg. 18, f. 250, 15/09/1469 y f. 262, 30/11/1469.

66 ACB, Lib. Reg. 18, f. 256v-266, 20/12/1469.

${ }^{67}$ ACB, Lib. Reg. 18, f. 268-269v, 05/01/1470.

68 ACB, Lib. Reg. 18, f. 286v, 06/04/1470.

${ }^{69}$ ACB, Lib. Reg. 18, f. 137, 05/08/1468.
} 
El arcediano de Burgos, en nombre del cabildo, subrayó este criterio, respondiendo que «estos señores estavan maravillados de agora faga tal innovaçión, aviendo tanto tiempo como el cabildo estava en posesión de poner bachilleres que enseñasen la dicha ciencia». Además, el beneficio anexo a este cargo era perpetuo ${ }^{70}$. El arcediano de Palenzuela redundó en el mismo criterio, señalando que muchos de ellos habían sido discípulos de este maestro. El maestrescuela interpeló al arcediano diciéndole que era su adversario y que no debería hablar en este asunto e insistió en que correspondía a su dignidad nombrar maestro para la escuela «sy algund tiempo lo avia dexado, que nin pudiéndose perdía su derecho, allegando algunas autoridades e rasones para ello» ${ }^{71}$. Dado que no hay constancia de la existencia de la figura del maestrescuela hasta mediados del siglo XV, estas palabras pueden interpretarse como una dejación de su derecho a hacer esta reclamación hasta ahora. Puede que lo intentara de palabra antes de acudir a la justicia eclesiástica.

La defensa del cabildo siguió la misma línea que la empleada en el asunto de los préstamos y la posesión de la canonjía unida a la dignidad de la maestrescolía. Una bula del Papa Calixto III (1455-1458) había revocado las otorgadas por su antecesor. Por lo tanto, la bula de Nicolás V (1447-1455) de anexión de préstamos y de una canonjía a la maestrescolía, así como de la canonjía de la escuela, quedaba invalidada, declarándose que el juez que expidió lo procesos apostólicos y cartas sobre esta bula no tenía jurisdicción en la diócesis. El tesorero de Burgos, que había sido designado por el maestrescuela como subejecutor se negó aduciendo estas razones ${ }^{72}$.

El cabildo defendió también al bachiller de Montealegre del intento por parte del maestrescuela de poseer la canonjía que aquel ocupaba desde hacía trece años. Según las costumbre de la Iglesia de Burgos, las dignidades no podían tener anexa más de una prebenda. Desde su punto de vista, el maestrescuela debía desistir de su intento de desposeer al bachiller de Montealegre. En éste, como en los otros puntos en discusión, instaron al maestrescuela a respetar el juramento de guardar los estatutos y costumbres de la Iglesia de Burgos. El maestrescuela señaló que él sólo estaba demandando lo que correspondía a su dignidad por derecho, siguiendo el consejo de letrados; y que, a pesar de haber obtenido letras pontificias para tomar posesión de la canonjía que ocupaba el bachiller de Montealegre, el cabildo estaba tratando de soslayar la jurisdicción del Papa y del Obispo ${ }^{73}$.

\footnotetext{
${ }^{70}$ Idem, f. $137 \mathrm{v}$.

${ }^{71}$ Idem, fol. $137 \mathrm{v}$.

${ }^{72}$ ACB, Lib. Reg. 18, f. 145, 12/08/1468.

${ }^{73}$ ACB, Lib. Reg. 18, ff. 150 y 155, 12/08/1468.
}

Hispania Sacra, LX

121, enero-junio 2008, 67-94, ISSN: 0018-215-X 
Sin duda, la réplica definitiva a la demanda hecha por el bachiller de la cátedra de la escuela de gramática se fundamentaba en los estatutos capitulares: «como es notorio que esta cátedra e escuela sea regido e gobernado por los señores del cabildo inmemorialmente, por disposición apostólica que es la Ynocençiana ${ }^{74}$, en referencia a las constituciones otorgadas al cabildo de Burgos por el legado pontificio Gil Torres (1250) y confirmadas por Inocencio IV en 1252. En ellas no aparecía la figura del maestrescuela como tal pero sí se contemplaba la enseñanza que debería proporcionar la escuela de la catedral.

En octubre de 1468, falleció al maestro de la gramática Juan Sánchez de San Martín. El cabildo inició el proceso para proveer la cátedra de gramática, ordenando que se pusieran cédulas en los Estudios Generales o universidades para todos aquellos que deseasen concurrir al examen ${ }^{75}$. En noviembre de 1468 se abrió un turno de oposición con tres candidatos: un bachiller de Villahoz, el bachiller Juan de Aguilar y Juan de San Martín, hijo del maestro fallecido ${ }^{76}$. Uno de los tres, Juan de Aguilar, examinador del Obispado de Burgos, recibió el apoyo del Obispo Acuña, que envió una carta al cabildo rogándoles que eligiesen a Juan de Aguilar, suficiente en doctrina y de buena conducta moral, además de acumular experiencia porque había enseñado en el Obispado de Segovia. Deducimos que pertenecía al círculo de familiares y criados que el Obispo Acuña se trajo de Segovia. El Obispo añadía en su carta que era beneficiado y preste (presbítero) ${ }^{77}$. El capiscol y el arcediano de Palenzuela, leída la carta, mostraron la conveniencia de agradar al Obispo, aunque matizaron que debían esperar por si viniesen otros candidatos más suficientes. Pero, el capiscol, aún dándose esta situación, apostando por el candidato del Obispo, dijo «que era rason aún que el dicho bachiller non fuese tan suficiente, que por rason e serviçio de señor obispo, lo oviesen antes el que otro»78.

${ }^{74}$ ACB, Lib. Reg. 18, f. 152v, 12/08/1468.

${ }^{75}$ ACB, Lib. Reg. 18, ff. 165 y 166v, 07/10/1468 y 15/10/1468.

${ }^{76}$ ACB, Lib. Reg. 18, f. 166v, 02/11/1468.

77 ACB, ACB, Lib. Reg. 18, f. 172v, 03/11/1468: «..E condiçion que la rija abriamos/, asad plaser las oviese Juan de Aguilar, nuestro examinador, que, syn dubda, es tan en/ sufiçiencia para esto in vita et in moribus, que su doctrina será provechosa a los/ escolares que del ovieron tanto. Y más que qualquier otro que esta vacante se oponga/ e gratificamos vos ser asy provechoso por que ya lo conocemos por/ experiencia en los tiempos que leyó en el Obispado de Segovia, quando nos en el presidíamos/. Por ende, mucho vos rogamos que deys orden a que él aya el cargo destas escuelas/, en la misma manera que el bachiller las tobo...».

En las iglesias parroquiales el término preste podía utilizarse para denominar a los presbíteros sin cura de almas que formaban parte de las mismas junto al cura, presbítero con cura de almas, vid. José Luis MARTín MARTín, «Beneficios y oficios de clero rural castellano (siglos XIII-XV)», en Anuario de Estudios Medievales, 35/2 (2005), p. 718.

${ }^{78}$ Idem, fol. $172 \mathrm{v}$. 
Protestó, como era de esperar, el maestrescuela López de Béjar, recordando que pertenecía a su dignidad proveer la cátedra de gramática de un maestro. Parece que en esta ocasión reforzó sus argumentos con citas de autoridades sobre el tema, trayendo libros, suponemos de derecho canónico, pues no se especifica. Una vez más, le respondieron que desistiese de solicitar esta función, que fue siempre del cabildo ${ }^{79}$.

Se acordaron las lecturas para los tres candidatos a la oposición a la cátedra de gramática: textos de gramática, en concreto, el Doctrinal de Alexandre de Villadieu (ca. 1199), otra gramática, la grafía es confusa en el original, quizás se trate del Graecismus de Ebrardo de Bétune, ca. 1212, e himnos. Se asignó un día de lectura a cada uno ${ }^{80}$. Días más tarde, el capiscol, vistos los tres candidatos opositores a la cátedra, solicitó que fuese proveída de la misma Juan de Aguilar, el bachiller examinador propuesto por el Obispo, del cual dijo «era sufeçiente, segund avya visto, e las qualidades que concurrían en él, ser benefiçiado e preste de misa e omme de buenas costumbres». No todos los capitulares aprobaron esta elección por lo que «... fueron algunas altercaçiones, desiendo unos que esta escuela requería omme de grand siençia» ${ }^{81}$.

Tuvo que intervenir el protonotario rogando a los señores del cabildo que tratasen de complacer el ruego del Obispo y evitar las diferencias de votos, alcanzando una concordia ${ }^{82}$. Lo capitulares ordenados in sacris, a quienes correspondía la provisión de beneficios, acordaron, tras un debate, proveer al bachiller Juan de Aguilar de la cátedra de gramática. Debería regir, administrar y leer en dicha cátedra o poner otros maestros que enseñasen a los mozos del coro y a escolares pobres ${ }^{83}$.

El maestrescuela López de Béjar se opuso y presentó un escrito de requerimiento pidiendo al deán y cabildo, que como «fijos de obediencia» de la Santa

${ }^{79}$ ACB, Lib. Reg. 18, f. 173, 03/11/1468: «el señor maestrescuela diso que sabía la merçed dellos como en vida/ del dicho bachiller e después se avía opuesto a esta cáthedra, desiendo/ pertenesçer le e ser devida a su dignidad. Por ende, que les pedía/ por merçed que se desistiesen deste caso. E que, pues a él pertenesçia en nombre/ de su dignidad de poner maestro, que él lo provería qual conbenía/, dando en guarda de su derecho asas rasones, asy por palabra/ commo por libros que traso por donde desía que lo proviesen».

${ }^{80}$ ACB, Lib. Reg. 18, f. 175, 03/11/1468.

${ }^{81}$ ACB, Lib. Reg. 18, f. 179v, 10/11/1468: «luego el señor capiscol propuso que ya sabia su merçed commo esta cáthedra de la/ escuela de gramática estava vaca e commo los que se avían opuesto avían/ leydo. E commo el bachiller examinador, por quien el señor Obispo les avía escripto/, era sufiçiente,segund avía visto, e las qualidades que concurrían en él, ser beneficiado/ e preste de misa e ome de buenas costumbres, que les ploguiese de gela dar./ Sobre lo qual, fueron algunas altercaçiones, desiendo unos que esta escuela requería/ ome de grand sçiencia e que devian enviar a otras partes como fuera otorgado/ e mandado...».

${ }^{82}$ ACB, Lib. Reg. 18, f. 180, 11/11/1468.

${ }^{83}$ ACB, Lib. Reg. 18, f. 180v, 12/11/1468.

Hispania Sacra, LX

121, enero-junio 2008, 67-94, ISSN: 0018-215-X 
Sede que eran, cumpliesen lo contenido en la bula de institución de la maestrescolía si no querían caer en las penas y sentencias. En la bula se caracterizaba al maestrescuela como «escolástico en la erudiçión e literatura de los escolares», manifestación que justificaría plenamente, a juicio del maestrescuela, los derechos inherentes a su dignidad en materia de docencia ${ }^{84}$.

El cabildo respondió al requerimiento y procedió a valorar el estado de las dos casas donde se ubicaba la escuela de gramática. El capiscol, que había tenido bastante protagonismo en las decisiones sobre la provisión de la cátedra de gramática, señaló las reparaciones que se debían acometer y el precio del alquiler de las escuelas al nuevo maestro ${ }^{85}$. Mientras, el cabildo presentó a la cátedra de teología de Bolonia a Nicolás Martínez de Cabezuela ${ }^{86}$.

La respuesta del cabildo al requerimiento esperó hasta marzo de 1469, momento en el que los capitulares habían pactado ya una concordia sobre los diferentes puntos en litigio. En lo referente a la cátedra y administración de la escuela de gramática, el maestrescuela debería aceptar que la competencia pertenecía al deán y cabildo ${ }^{87}$. Ya vimos cómo el enfrentamiento no terminó con esta concordia sino que se agudizó, pero este punto del conflicto no vuelve a aparecer hasta la sentencia final y arrepentimiento del maestrescuela, una vez que fue privado de libertad.

En 1472 renunció del todo a las competencias en enseñanza, propias de la figura del maestrescuela en otras catedrales. Triunfó el reconocimiento de la costumbre y de los «derechos inmemoriales» del cabildo en la provisión y regimiento de su escuela de gramática ${ }^{88}$. Puede que el capiscol fuera el más interesado en preservar el control de los nombramientos de maestros para la

${ }^{84}$ ACB, Lib. Reg. 18, f. 181, 12/11/1468.

${ }^{85} \mathrm{Idem}$, fol. 181:«quanto a lo de la casa que ya verya que era necesario, que avían/ de leer en ella este bachiller. E por quanto se diso que avía dos casas/ que se viese la que podía quedar della e asy mesmo/ que la casa estava mal reparada, que la devía reparar. E asy mesmo que estas casas valían mucho más, que valían mas de tres / mil maravedís, el señor capiscol diso que las devía desar e que/ diese dos mill».

${ }^{86}$ ACB, Lib. Reg. 18, f. 181v, 12/11/1468: «este día los dichos señores presentaron la cathedra de/ teología de Bolonia a Nicolás Martínes de Cabezuela syn perjuyçio de otro».

${ }^{87}$ ACB, Lib. Reg. 18, f. 214, 03/03/1469: «proveyeron quanto a lo de la cáthedra, solas cabsas ya dichas, que la den/ libre a los señores deán e cabildo la administración e su provisión/ que siempre tovieron e non se entremetiera más.»

${ }^{88}$ ACB, Lib. Reg. 18, f. 414v, 31/01/1472: «que por quanto sobre la creación de su dignidad, el ha atentado de faser/, de fecho e contra todo derecho, muchas e diversas deligençias e auctos. los quales/ non se respondieron, pues que son yerros. Que quanto es a la administraçión/ de la escuela de la gramática, que commo la ovo desado completamente, que asy/ agora ratificando aquella, sy neçesario es, de nuevo la desa a los dichos/ señores, pues paresçe que de tiempo inmemorial e de antigua costumbre, siempre/ se rigió la dicha escuela, dando e proveyendo por su mandado que toviese/ e fesiese la dicha cáthedra de la dicha escuela». 
escuela, dado el peso que su voz adquirió en la provisión de la cátedra de gramática.

\section{La imagen de la jerarquía capitular: la silla en el coro y en el cabildo}

El problema del lugar que el maestrescuela debía ocupar en el coro no quedó resuelto hasta 1473 . En este momento, el maestrescuela había ya desistido de sus demandas más conflictivas y el cabildo había afirmado las costumbres que blindaban los intereses de su alta jerarquía. La provisión de la abadía de Castro reabrió el debate. Esta vez, Rodrigo Sánchez de Arévalo, nuevo abad de Castro, entabló una discusión con el maestrescuela López de Béjar sobre la silla del coro. El maestrescuela decía que su silla estaba debajo de la del arcediano de Palenzuela, donde se la habían adjudicado el cabildo y el Obispo. El abad de Castro alega que la silla de la abadía debía ir primero pues era más antigua que la de la maestrescolía creada «nuevamente».

El cabildo dejó a los letrados el examen del caso. El maestrescuela argumentó que en la bula de institución de la maestrescolía se contenía que la silla del maestrescuela debía estar por encima de la de los abades. Los letrados examinaron la bula y las constituciones conocidas por los capitulares como la «Inocenciana» ${ }^{89}$. La sentencia fue que, de acuerdo con las bulas de institución de la maestrescolía, el maestrescuela debía ocupar la silla situada debajo de la del arcediano de Palenzuela y el abad de Castro la siguiente por debajo ${ }^{90}$.

Puede decirse que este fue el último capítulo de la lucha que el maestrescuela llevo a cabo contra el cabildo. La sentencia le fue seguramente favorable entonces porque, como veremos seguidamente, había iniciado el camino de la reconciliación.

EL FINAL DEL CONFLICTO: EL ARREPENTIMIENTO Y LA RESTITUCIÓN DE LA «FAMA» DEL CABILDO CATEDRALICIO

En el breve plazo de dos años, entre 1470 y 1471, la confrontación entre el cabildo y el maestrescuela López de Béjar se precipitó hacia su final, pero afloró el principal tema de debate: la reclamación de beneficios y préstamos por el maestrescuela. Una vez más, el cabildo respondió utilizando la medida del encarcelamiento y el maestrescuela recurrió a la obtención de cartas de excomunión como medio de presión. Un nuevo elemento entró en escena, una mayor

${ }^{89}$ ACB, Lib. Reg. 18, ff. 491v-493, 04/06/1473.

${ }^{90}$ ACB, Lib. Reg. 18, f. 494v, 21/06/1473.

Hispania Sacra, LX

121, enero-junio 2008, 67-94, ISSN: 0018-215-X 
intervención de los poderes laicos. La posición del Obispo Acuña estuvo determinada por el hecho de que López de Béjar era su vicario en aquellos momentos. El cabildo se vio obligado a atajar con celeridad un conflicto pues entendía que afectaba seriamente su reputación.

\section{La implicación de los poderes laicos}

El maestrescuela intentó privar a algunos beneficiados de la Iglesia catedralicia de sus beneficios y perturbar la celebración de los oficios divinos. Ante estos hechos, el cabildo le acusó en mayo de 1470 de perjurio ${ }^{91}$. Fue puesto de nuevo en prisión en la sala de la mesa capitular de la Catedral. Esta vez, los capitulares introdujeron un argumento nuevo acusatorio, que revelaba la implicación en el conflicto de los poderes laicos: el maestrescuela «...avía procurado fabores temporales e parçialidad con algunos señores de la çibdad en gran escándalo e peligro» 92 .

Cuatro meses antes de estos hechos, López de Béjar había ya avalado la reclamación del cobro del fruto de sus beneficios mediante una carta de la condesa de Plasencia, esposa del alcaide del castillo de Burgos ${ }^{93}$. El cabildo llegó entonces a plantearse la supresión de la maestrescolía, enviando a Roma al arcediano de Lara. Pero, en cierta medida, la detención del maestrescuela se volvió en contra suya, introduciendo en el conflicto al alcaide de la fortaleza y a los regidores de la ciudad, ejecutores de la orden de detención. En el escenario de disturbios y violencias que habían provocado en la última década y media los enfrentamientos entre la ciudad y los tenentes del castillo, la extensión del conflicto con el maestrescuela era la consecuencia menos deseada por la Iglesia burgalesa. Al mismo tiempo, el Obispo Acuña adquirió un protagonismo directo en la confrontación y, abandonando su fortaleza de Rabe, se dirigió a Burgos.

Los miembros del cabildo concentraron sus esfuerzos en convencer al alcalde del castillo y al Obispo Acuña de la conveniencia del apresamiento del maestrescuela. El alcaide del castillo recelaba ahora de haber ejecutado la detención de la dignidad catedralicia «sobre el seguro» que los capitulares le habían dado.

91 ACB, Lib. Reg. 18, f. 290v, 02/05/1470: «los dichos señores diseron que por quanto el señor maestrescuela don Alonso Lópes, por ciertos insultos, delitos/, escándalos, cometidos por él en esta iglesia. E en diversas veses, asy en les aver turvado e turvar/ en los divinales ofiçios, como en procurar privaçion de los beneficios de algunos señores beneficiados/ de la iglesia contra el thenor e forma del juramento que tienen fecho. E asy, por ello, ha incurrido en pena de/ perjurio e, asy mesmo, avía destraydo e maltratado a sus ofiçiales contra toda justicia, por dar/ mengua a la iglesia e turbaçión a los dichos señores della con gran escándalo e perjuiçio dello...».

${ }^{92}$ ACB, Lib. Reg. 18, f. 291, 02/05/1470.

93 ACB, Lib. Reg. 18, f. 278v, 19/02/1470. 
El alcaide profirió, además, amenazas a los diputados del ayuntamiento de la ciudad que habían recibido igualmente órdenes de prender al maestrescuela. Los señores del cabildo negaron al alcaide del castillo haberle dado tal «seguro» y le instaron a acatar la «dignidad de esta iglesia», a la cual él, como otros señores de su rango, se debía. Tras informarle en detalle de los agravios del maestrescuela, el alcaide retiró sus amenazas ${ }^{94}$. Sin embargo, el Obispo Acuña rogó que liberasen al maestrescuela y estudiasen las medidas contra él, si no se retractaba de sus actos. El cabildo convenció al Obispo para que, al menos, estuviese retenido en su casa pues «este ombre estava tan endurecido» que «en lo soltar le pondrá en más turbaciones» ${ }^{95}$. De ello, informaron cumplidamente a los condes de Plasencia, tenentes del castillo

\section{La estrategia del maestrescuela y las cartas de excomunión}

La privación de libertad del maestrescuela López de Béjar se vio compensada por las facultades jurisdiccionales que su condición de vicario del Obispo le otorgaba. Una nueva serie de cartas de excomunión, dictadas por el maestrescuela como vicario del Obispo, forzaron al cabildo a solicitar al prelado que retirase de su oficio a López de Béjar ${ }^{96}$. Comenzó éste mandando cartas de excomunión al cantor y a ciertos capellanes, de los que decía que «pusieron manos airadas en él» cuando le detuvieron celebrando misa.

Los señores del cabildo pidieron al Obispo que revocase las cartas de excomunión. El arcediano de Lara y otros dos canónigos fueron puestos en entredicho por un mandato que el maestrescuela les había hecho desde la ventana de la mesa capitular, donde se hallaba encerrado, cuando ellos pasaban por la plaza del Sarmental. La actitud del Obispo no agradó al cabildo pues les enviaba ahora los mandamientos revocados por juez y notario ${ }^{97}$. A esto se unió la licencia solicitada por el maestrescuela para permutar la canonjía de Juan de Maluenda que había ocupado como intruso durante tres años. El cabildo le demandaba tres mil maravedíes por los frutos llevados de esta canonjía y le concedieron la licencia a condición de sufragar esta deuda ${ }^{98}$.

En 1471 continuaron los problemas con el maestrescuela. No sabemos si permaneció privado de libertad este año. Resulta dudoso porque en abril se le prohibió entrar al cabildo y en la iglesia para evitar que leyese las ya citadas

\footnotetext{
94 ACB, Lib. Reg. 18, ff. 291-291v, 02/05/1470.

${ }_{95}$ ACB, Lib. Reg. 18, f. 292v, 02/05/1470.

${ }^{96}$ ACB, Lib. Reg. 18, f. 304v, 27/06/1470.

${ }^{97}$ ACB, Lib. Reg. 18, f. 304v, 22/06/1470 y f. 307v, 23/06/1470.

98 ACB, Lib. Reg. 18, f. 315, 21/07/1470.
} 
cartas de excomunión. Al mismo tiempo, se le acusó de haber incumplido el mandamiento, implícito en su juramento de toma de posesión de la maestrescolía, de guardar los secretos del cabildo. Los capitulares decían estar informados de que difundió asuntos tratados en é199. Se abrió entonces otro frente relativo a los préstamos de la Iglesia de San Pedro de Pampliega que el Papa había anexionado a la mesa capitular y se hallaban en manos del arcediano de Lara. El maestrescuela había puesto cédulas en las puertas de la iglesia para que los que los quisieran arrendar se dirigieran a él. El cabildo le denunció afirmando que dos partes de estos préstamos le pertenecían y una tercera pertenecía al monasterio de San Ildefonso desde hacía cinco años ${ }^{100}$.

La prohibición al maestrescuela de entrar en la iglesia no evitó que en septiembre leyese cartas de excomunión contra algunos beneficiados. Como en ocasiones anteriores, el cabildo negó la validez de las mismas por haber sido otorgadas por un juez sin jurisdicción autorizada por el Obispo de Burgos. Los miembros del cabildo se sintieron gravemente injuriados, volvieron a discutir sobre el apresamiento del maestrescuela e informaron del suceso al Obispo ${ }^{101}$. Incluso ordenaron a su sobrino Fernando López de Béjar que se alejase de él102.

López de Béjar jugó entonces su última carta: hizo llegar al cabildo a través del secretario del alcaide del castillo un requerimiento con los procesos apostólicos ejecutoriales dirigidos al alcalde, al deán y cabildo de Burgos. Citaba a siete capitulares de los que decía que «están descomulgados e demandados» por negarse a ejecutar dichos procesos. Además, se quejaba de que habían hecho prender a los clérigos que debían leer las cartas emitidas por el subejecutor de los procesos. Por ello, ningún clérigo, ni notario osaba ya a publicar o leer estos mandatos y él no podía perseguir su causa. Acusó a los miembros del cabildo de usar la fuerza y no la justicia: «porque usan de fecho en non de justicia». En consecuencia, requirió al alcaide que como «católico caballero» le diese «favor e ayuda» contra el cabildo, haciendo leer y cumplir las dicha cartas de excomunión ${ }^{103}$.

La reacción del cabildo fue ahora frontal: «diseron que allende de las otras injurias e males que avía fecho esta avía seydo la mayor requerir a la justicia» ${ }^{104}$. Recurrir en última instancia a la justicia laica que representaba el alcaide de la fortaleza había sido la gota que colmó el vaso. Inmediatamente, solici-

\footnotetext{
${ }^{99}$ ACB, Lib. Reg. 18, f. 368, 27/04/1471.

100 ACB, Lib. Reg. 18, f.384, 02/08/1471.

101 ACB, Lib. Reg. 18, f.338, 05/09/1471.

102 ACB, Lib. Reg. 18, f.391v, 25/09/1471.

103 ACB, Lib. Reg. 18, ff. 392v-393, 27/09/1471: los capitulares excomulgados son Ferrand Díaz, capiscol, Sancho Sánchez, arcediano de Lara, Juan Martínez de Comparada, abad de San Millán, Juan Sánchez de Sepúlveda, Pedro García de Lalo, Juan López y Pedro Rodríguez de Grijera.

104 Idem, fol. 393.
} 
taron al protonotario merced y gracia para encarcelar al maestrescuela y llevar el asunto a Roma a través de un beneficiado nombrado para ello ${ }^{105}$.

\section{Las condiciones del perdón}

El último episodio de esta larga confrontación fue la escena de arrepentimiento de López de Béjar. Posiblemente no recibió el favor que esperaba del alcaide del castillo. Puede que comprendiese que la ejecución de los procesos y cartas obtenidos continuaría chocando con el muro infranqueable de un cabildo dispuesto a defender su estatus y costumbres al amparo de la libertad que le otorgaba su condición de sede exenta. Lo cierto es que en enero de 1472 el maestrescuela López de Béjar, logrado el perdón del protonotario, entró de nuevo humildemente en el cabildo para suplicar perdón a los capitulares por sus «culpas e yerros». Se le permitió entrar en el coro, jurando solemnemente no mover pleito alguno contra ellos, acatar su decisión y no pedir rebaja o absolución de este juramento al Papa o a autoridad alguna ${ }^{106}$.

El perdón conllevaba una serie de condiciones que los señores del cabildo discutieron largamente y se concretaron en los siguientes puntos ${ }^{107}$. En relación con la cátedra y escuela de gramática, el maestrescuela debía ratificar el reconocimiento de que su administración pertenecía a los señores del cabildo desde tiempo antiguo. En cuanto a la silla del coro, el maestrescuela consintió al tiempo de su recepción en la institución la que ahora tenía asignada. Se admitió que pudiese demandar otra silla pero debería hacerlo por vía judicial en la Corte de Roma.

Las canonjías o prebendas, anexas a su dignidad, debían tener dos, como estipulaban las costumbres y constituciones de la Iglesia de Burgos que habían de tener las dignidades. Había tratado de tener tres. En caso de que, por derecho, obtuviera finalmente la prebenda en litigio, debería renunciar a ella y permutarla, de manera que disfrutase solamente de dos prebendas como las otras dignidades ${ }^{108}$.

105 Idem, fol. 393: añade además que le han «...tomado mas de çiento e treynta mil maravedíes de mis/ calongías, que en esta dicha iglesia tengo. E mas de çien fanegas de pan de tres años/a esta parte, los quales me tienen tomados e ocupados contra Dios e contra sus/ consçiencias, allende de otros muchos agravios e opresiones e violencias e presión / que me han fecho...».

106 ACB, Lib. Reg. 18, ff. 410-411, 04/01/1472.

107 ACB, Lib. Reg. 18, ff. 414v-415, 31/01/1472.

108 ACB, Lib. Reg. 18, f.415, 31/01/1472: «e quanto es a lo terçero, que el procurava tener dos prevendas anexas a la dignidad, / que asy serían tres con la que agora tiene, que esto sería contra los privillejos/ apostolicos e constituciones e ordenaciones e costumbres de la iglesia. Que non pueda procurar/, nin procure, nin tenga mas de dos prevendas, como todas las dignidades/siempre tovieron e tienen commo antes de agora la tiene otorgada. En tal manera,/ que non sea más de una prevenda anexa a la dignidad e que, en caso que de derecho/ oviese la dicha prevenda que litiga, que sea teniendo de luego

Hispania Sacra, LX

121, enero-junio 2008, 67-94, ISSN: 0018-215-X 
Debería traer en el plazo de tres meses la revocación y anulación los autos, procesos y cartas que procuró ante diversos jueces, Plasencia, Husillos, Palencia... contra personas del cabildo de Burgos. Si no pudiere conseguirlo en ese plazo, se le ampliaría dos meses más. Se reconocía su derecho a seguir litigando por vía judicial contra el arcediano de Palenzuela sobre los préstamos, con Pedro Fernández sobre una canonjía y con Juan Fernández de Villaldemiro ${ }^{109}$.

Hubo acuerdo sobre las rentas derivadas de sus prebendas y las distribuciones cotidianas de las que había sido privado durante la duración del conflicto. En septiembre de 1472, determinaron entregarle, desde ese momento y durante el próximo año y medio, todo lo que había ganado. Se le registrarían desde la citada fecha hasta el mes de junio veinte mil maravedíes por sus dos prebendas, como le hacían al arcediano de Palenzuela.

Finalmente, se había doblegado López de Béjar ante el peso de las costumbres de la vieja institución catedralicia. La tradición había actuado como salvaguarda de sus derechos y privilegios.

\section{CONCLUSIONES}

La introducción de la figura del maestrescuela entre las dignidades del cabildo de la Catedral de Burgos a mediados del siglo XV (hacia 1454-1455) causó un conflicto que revela el grado de autonomía de la institución frente a otras instancias del poder eclesiástico y laico. El maestrescuela López de Béjar, integrado pacíficamente en la vida capitular, comenzó, a partir de 1467 a reivindicar los derechos derivados de la bula apostólica de institución de la maestrescolía, otorgada por Nicolás V, es decir, la dirección y administración de la escuela de gramática. Desatendidas sus demandas, recurrió a la justicia pontificia.

Varios indicios vinculan a López de Béjar con la diócesis de Plasencia: era arcediano de Béjar cuando fue provisto de la maestrescolía de Burgos, la elección del tesorero y provisor del Obispo de Plasencia como juez ejecutor de la bula y los procesos sobre ella formulados y la intervención de Álvaro de Estúñiga, conde de Plasencia y tenente del castillo de Burgos, en los acontecimientos.

\footnotetext{
la permutar e renunçiar/ De tal manera, que non pueda tener salvo las dichas dos prebendas, una anexa/ e otra como las otras dignidades e fasta entonçes non sea resçebido nin puntado».

109 ACB, Lib. Reg. 18, f. 415, 31/01/1472: «...e dentro de tres meses/ primeros, segund trahera de los dichos jueses e de cada uno dellos, quitaçión/ e revocaçión/ e anullaçión de todos los derechos, autos e proçesos e cartas. Reservando/ e quedando le siempre a salvo su derecho que tiene o pretende tener sobre que litigar con/ el benerable hermano arçediano de Palençuela sobre los préstamos, e/ Pero ferrandes de Pino sobre la calongía. E quanto es a Juan Ferrandes de villaldemiro/..quien se dise que tiene litijio en corte de roma...».
} 
El papel del Obispo Acuña en el afianzamiento de la nueva dignidad catedralicia es más difícil de explicar con la documentación utilizada. Sin embargo, el intento del maestrescuela de adecuar sus funciones a las que solía desempeñar esta figura en otras catedrales coincide con el espíritu de las reformas que el Obispo impulsó. Tuvo Acuña que enfrentarse a la autonomía del cabildo burgalés, que se amparaba en su condición de sede exenta. La lejanía de Roma les había proporcionado siempre la libertad para hacer valer sus costumbres.

La principal defensa de la institución ante el desafío planteado por el maestrescuela fue la existencia de «derechos de tiempo inmemorial» que todo beneficiado acataba con el juramento que estaba obligado a realizar en la toma de posesión de guardar los estatutos existentes. Calificando como «innovaciones» las reivindicaciones del maestrescuela, aseguró el cabildo el recurso a la «antigüedad», pilar fundamental de sus constituciones y su mejor argumento. Al mismo tiempo, recurrieron a otros legales para invalidar los documentos en los que el maestrescuela basaba sus demandas. El cabildo no siguió la vía judicial en la Corte de Roma contra el maestrescuela hasta que las sentencias de excomunión obtenidas por este último amenazaron la reputación de algunos de sus miembros. Ambas partes se acusaron de injuria.

El temor a una proyección exterior del conflicto probablemente motivó la decisión de privar de libertad al maestrescuela durante su fase más aguda (1468-1471). La lectura de las cartas de excomunión durante la celebración de las horas canónicas en la Iglesia y la petición de ayuda a autoridades laicas supusieron una afrenta intolerable para los capitulares. Estos acontecimientos y la prisión del maestrescuela forzaron la mediación del Obispo. Puede que su intervención y el bloqueo del cabildo a la ejecución de las sentencias obtenidas por el maestrescuela convencieran a éste de la necesidad de alcanzar una concordia. Lo cierto es que desistió de su solicitud de una canonjía y de los préstamos anexos a la maestrescolía. Renunció a su reivindicación de la regencia y administración de la escuela de gramática. A cambio, el maestrescuela exigió la devolución de las rentas derivadas de sus prebendas, de las que había sido privado durante el conflicto. Pero la renuncia a sus reivindicaciones no era suficiente. Los actos protagonizados por López de Béjar fueron llevados al terreno moral, siendo calificados como «yerros». Finalmente, el arrepentimiento público exteriorizaba su culpabilidad y salvaguardaba la fama de la institución catedralicia. 